\title{
Eflatun Ktz within the Context of Translation Studies: A Conceptual (Re)Framing
}

\author{
Hülya BOY*
}

This study aims to question the requirement and feasibility for new conceptualizations within the context of Translation Studies through rethinking the translational adventure of Eflatun $K l z$ by Nihal Yeğinobali. What constitutes the motive of this questioning is the existence of Eflatun $\mathrm{Klz}$ in the Turkish literary system in three different periods under different classifications as 'original' and 'translation.' Eflatun $K l z$ was serialized as an indigenous literary novel in 1957; it was printed in book form as a translation in 1964; and it was published as an original with the title Mazi Kalbimde Bir Yaradir in 1988. The point of departure of this study is the argument that the 1964 text regarded as a 'pseudo-translation' is based on the 1957 serial novel serving as the source text while pseudo-translations stand for "texts which have been presented as translations with no corresponding source texts in other languages ever having existed" (Toury 1995, 40). In this sense, considering the existence of the serial novel as a corresponding physical source text, the case of Eflatun $K l z$ is discussed within the context of pseudo-translation, paving the way for a re-reading also through the concepts of intralingual translation, self translation, and concealed translation. As a result, "concealed intralingual self translation" is suggested as a concept depending on the concept of "intr-auto-translauthor" (Canlı and Karadağ 2017). The intralingual translational relation between the three Eflatun $K l z$ texts is examined based on the source-text postulate, the transfer postulate, and the relationship postulate of Toury's (1995) "notion of assumed translation."

Keywords: Eflatun Klz; pseudo-translation; intralingual translation; self translation; concealed translation

\section{Introduction}

Pseudo-translations refer to texts presented and thus received as translations for any reason in a target literary and cultural system in spite of the fact that they are actually original writings themselves (Toury 1995, 40). Through the providing of an insight into general social and cultural characteristics, as well as dominant literary norms of the related target system of a specific period, they are among the most noteworthy objects of study in the field of Translation Studies.

\footnotetext{
${ }^{*}$ Research Assistant at Marmara University, Istanbul; PhD student at Y1ldız Technical University, Istanbul. Email: hulya.boy@marmara.edu.tr
} 
Considering pseudo-translations emerging as intriguing facts of the Turkish literary and cultural system, translator and writer Nihal Yeğinobalı's novel Genç Kızlar (Young girls) which was first published in 1950 by Türkiye Publishing can be regarded as one of the most well-known examples. The status of Genç Kızlar as a pseudo-translation was first brought to light by Translation Studies scholar Işın Bengi-Öner ([1990] 1999) in her pioneering study entitled "Çeviribilim, Çeviri Kuramı ve Sözde Çeviriler" (Translation Studies, translation theory and pseudo-translations). ${ }^{1}$ As highlighted by Bengi-Öner (25-26), Genç Klzlar was initially presented as a novel authored by Vincent Ewing and translated into Turkish by Nihal Yeğinobal1; furthermore, the first edition by Türkiye Publishing — the front cover and inner cover page of which are shown in figure 1 - even included an introduction about the pseudowriter, along with a portrait of him, as well as the title of the pseudo-original: The Curtain Sweeps Down.
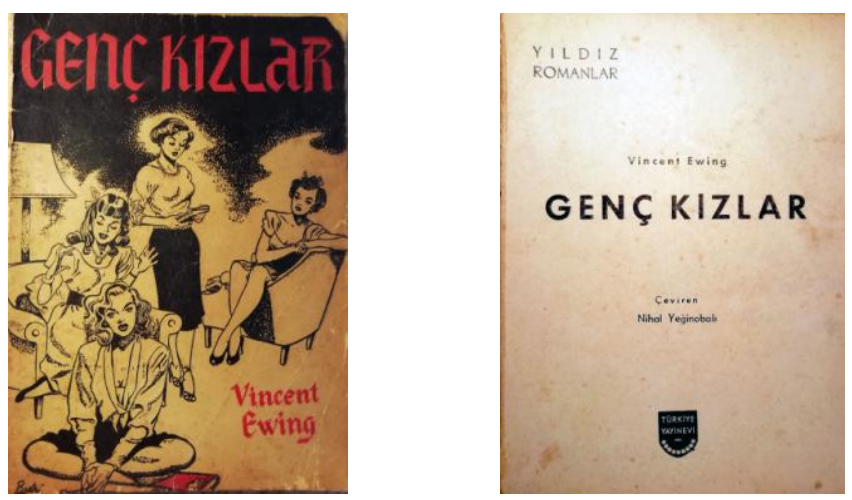

Figure 1. Front cover (left) and inner cover page (right) of Genç Klzlar's (1950) first edition by Türkiye Publishing.

It was not until the late 1980's that the fact Genç Kızlar was not actually a translation but an indigenous literary work by Nihal Yeğinobalı herself attracted remarkable public attention when Tarık Ersoy's interview with Nihal Yeğinobalı was published with the heading "Utandığım İçin Açıklayamadım" (I couldn't explain because I was embarrassed) in the newspaper Cumhuriyet dated 5 June $1988 .^{2}$

\footnotetext{
${ }^{1}$ First published in 1990 in the journal Dilbilim Araştırmalarl, available at http://dad.boun.edu.tr/issue/29234/312970 (last accessed December 25, 2018).

${ }^{2}$ Although nearly twenty years before this date Nihal Yeğinobalı made it public in the newspaper Vatan that in fact she was not the translator but the writer of Genç Klzlar, this disclosure did not spark off any significant public reaction (Bengi-Öner 1999, 38).
} 
Genç Kızlar was analyzed in various other comprehensive studies (see Öztürk Kasar and Gün Birdane 2006; Alt 2008; Öztürk Kasar 2009; Tahir Gürçağlar 2010) by researchers in Translation Studies within the context of pseudo-translation from different perspectives while the novel Eflatun Klz (Lilac girl) published in 1964 by Altın Kitaplar, bearing the same pseudo-writer's name, was regarded as Nihal Yeğinobalı's second case of 'pseudo-translation' (Öztürk Kasar 2009, 189; Tahir Gürçağlar 2010, 176). Specifically aimed at a conceptoriented rethinking, the present study departs from the existence of a physical source text on which the 'pseudo-translation' Eflatun Klz is actually based. In the Turkish literary system, Eflatun $\mathrm{Klz}$ exists as three different text versions which are chronologically as follows:

- $\quad$ Eflatun Klz. Writer: Nihal Yeğinobalı. Vatan. 23 April-29 July 1957.

- Eflatun Klz. Writer: Vincent Ewing. Translator: Nihal Yeğinobalı. Altın Kitaplar. 1964.

- Mazi Kalbimde Bir Yaradir (The past is a wound in my heart). Writer: Nihal Yeğinobal1. Cem. 1988.

The point to be emphasized here is that the first and the third of these versions were presented as 'originals' while the second version was presented as 'translation.' To be more precise, Eflatun $\mathrm{Klz}$ was initially serialized in the newspaper Vatan from April 23 to July 29 1957 as an indigenous novel written by Nihal Yeğinobalı. It was printed in book form in 1964 by Altın Kitaplar as a novel written by Vincent Ewing and translated by Nihal Yeğinobalı. Finally, in 1988, it was once more published, and on this occasion by Cem again as an indigenous novel written by Nihal Yeğinobal1; however, now with the title of Mazi Kalbimde Bir Yaradır. ${ }^{3}$ At this very point, it may prove useful to note that the year in which the serials were published was stated as being 1959 in previous studies (Öztürk Kasar 2009, 192; Tahir Gürçağlar 2010, 176) on the basis of the information provided by Nihal Yeğinobalı herself in interviews one of which, for instance, includes her following statement:

And there is also Eflatun Klz. I went to America in the midst of all this hustle and bustle. I would go and come back very often. Once, when I came back, I wrote Eflatun $K ı z$. The newspaper Vatan then. It was also liked very much, it became a hit. I wrote

\footnotetext{
${ }^{3}$ There seems to be a disagreement in print and electronic sources as to the year of publication of Mazi Kalbimde Bir Yaradır's first edition by Cem. While the year is stated as being 1987 in some of these sources, the findings obtained within the scope of this study indicate the book was first released in 1988, depending on the fact that no edition dated 1987 is available in libraries or booksellers and the 1988 issues of the newspaper Cumhuriyet include the first advertisements of the book, the accessed 1988 copies belong to the second edition including also the one used in this study, though.
} 
and sent the last two or three chapters from America. It was around the year 59. ${ }^{4}$ (Alt 2008, 96; emphasis added)

It should be acknowledged that the process of existence of the 1957 Eflatun Klz text differs from that of the other two in physical terms. While the 1964 and the 1988 texts published and republished in book form - are much more readily available to readers of different periods, the story was apparently not the same regarding the 1957 text which was itself serialized in a newspaper for about three months from April to July 1957 resulting in a total of 93 chapters. ${ }^{5}$ Indeed, the source text in serial form was in time forgotten in some way by the readers of the related period, and even when set forth under the same title but now as a translation seven years later in 1964, it seems to have generated no significant reaction. In the light of these findings, this study suggests that three main reasons might have contributed to the consideration of the 1964 text being a 'pseudo-translation' despite the knowledge of a preceding text:

- Existence of Genç Kızlar as a previous case of pseudo-translation by Nihal Yeğinobal1.

- Non-access to the serials due to the ambivalent information provided by Nihal Yeğinobalı regarding year.

- The tendency in general to consider translation in the 'proper' sense, namely, initially as interlingual translation.

Starting from the fact that the 1957 serial novel exists as a source text which served as a basis for the 1964 'pseudo-translation,' this study aims to analyze the translational adventure of Eflatun $\mathrm{Klz}$ in the Turkish literary system aspiring to find out whether the case of Eflatun $K l z$ can be reframed within the context of Translation Studies paving the way for possible new conceptualizations. To this end, after a brief look at the adventure of the literary work from Eflatun Klz to Mazi Kalbimde Bir Yaradır, the case is discussed within the context of pseudotranslation, intralingual translation, self translation, and concealed translation, respectively. Following the conceptual discussion and suggestion of a possible reframing, the intralingual translational relations of the three Eflatun $\mathrm{Klz}$ texts are analyzed based on the source text postulate, the transfer postulate, and the relationship postulate of Gideon Toury's (1995, 3335) "notion of assumed translation."

\footnotetext{
${ }^{4}$ Unless otherwise noted, all translations are my own.

5 The last chapter bears the number 92 as the one which should have been numbered 84 was mistakenly numbered 83 .
} 


\section{From Eflatun Kız to Mazi Kalbimde Bir Yaradır}

Eflatun $K_{l z}$ was first presented and received in the Turkish literary system as an indigenous literary work by Nihal Yeğinobalı when it was first serialized in the newspaper Vatan between April 23 and July 29 1957. As seen in figure 2, the first advertisement of the serial novel incorporated a picture of Nihal Yeğinobalı as the writer, along with an illustration - used in all 93 chapters - depicting a young woman and a man hugging each other, and the following information: "Eflatun Klz. In this novel, you will find all graces of a woman's soul. Written by: Nihal Yeğinobalı."
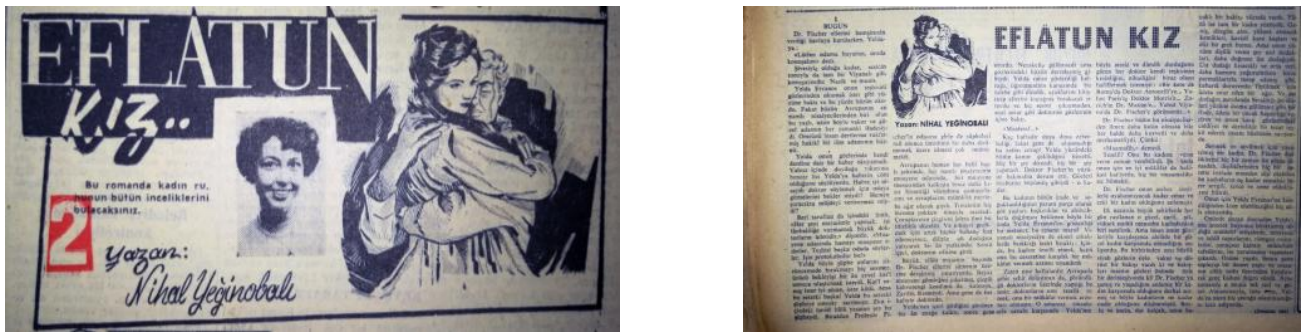

Figure 2. Serial novel Eflatun Kız's first advertisement (left) dated 21 April 1957 and the first chapter (right) dated 23 April 1957 in Vatan.

When Eflatun Klz, which tells the story of a woman caught between two lives wavering between her first love and her husband, was first set forth, Nihal Yeğinobalı was already known as the translator of the celebrated novel Genç Klzlar which had attracted a great deal of interest among readers. And now, 7 years later, she was again in front of the readers with Eflatun Klz published under her own name. Like Genç Kızlar, Eflatun Kız, in Nihal Yeğinobalı's words, "was also liked very much, it became a hit" (Alt 2008, 96). According to the story told by Nihal Yeğinobalı in her interview with Nil Alt (2008, 96-97), many publishers wanted to release Eflatun $K l z$ in book form; however, it remained unrealized as she suddenly went back to America. A few years later when she was back in Turkey, she - then in need of money - talked to several publishers in order to have Eflatun $K ı z$ published but received the response "Which Eflatun Klz?". The serial novel was somehow forgotten. She subsequently received an offer from Altın Kitaplar which was then newly being established and which wanted to publish Genç Kızlar rather than Eflatun Kız. Due to commercial concerns, the owner of the publishing house preferred to present Nihal Yegrinobalı as a translator rather than as a writer not only with Genç Kızlar but also with Eflatun Kız. 
Having financial problems, she had no other choice but to agree. After the publication of Genç Klzlar again under the name of the pseudo-writer Vincent Ewing, Eflatun Klz was published by Altın Kitaplar as a translation in 1964.
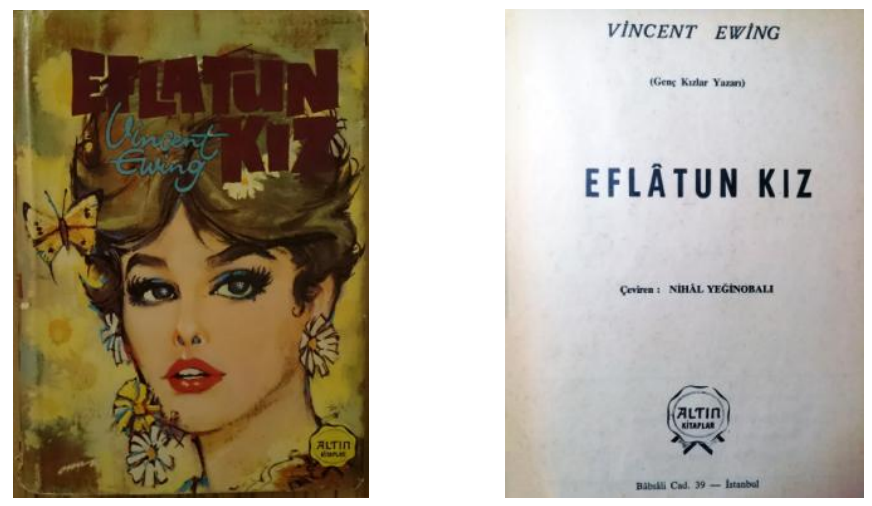

Figure 3. Front jacket (left) and inner cover page (right) of Eflatun Klz's (1964) first edition by Altın Kitaplar.

In the first edition in book form of Eflatun $\mathrm{Klz}$ in 1964 by Altın Kitaplar, as shown in figure 3, Vincent Ewing was introduced as the writer, with an emphasis given in parentheses as "the writer of Genç Klzlar", and Nihal Yeğinobalı was presented as the translator. As underlined in the previous parts of the study, this did not bring about any major public reaction and Eflatun $K l z$ was received as an interlingual translation by the readers. In this version of the text, which was actually rewritten in the same language by Nihal Yeğinobalı herself based on the 1957 source text, the plotline remaining the same, the story was taken to a foreignized context in order to give the text a scent of translationese which was also supported with the addition of a total of four translator notes throughout the whole text. Considering the way in which the novel was presented, this is indisputably an understandable strategy to persuade the readers of the existence of a foreign language source text; the point here, on the other hand, is the fact that the real source text was in Turkish: The once forgotten serial novel Eflatun Klz.

For a period of nearly a quarter of a century, Eflatun Klz continued to exist within the Turkish literary system as a seemingly interlingual translation. It was in the year 1988 that it was published by Cem as an indigenous novel authored by Nihal Yeğinobalı (see figure 4). This third version - rewritten in the same language with the same plotline but with remarkable additions in particular - was titled Mazi Kalbimde Bir Yaradır with reference to 
the song known as the first Turkish tango. This, as a theme, was originally evoked in the 1957 source text.
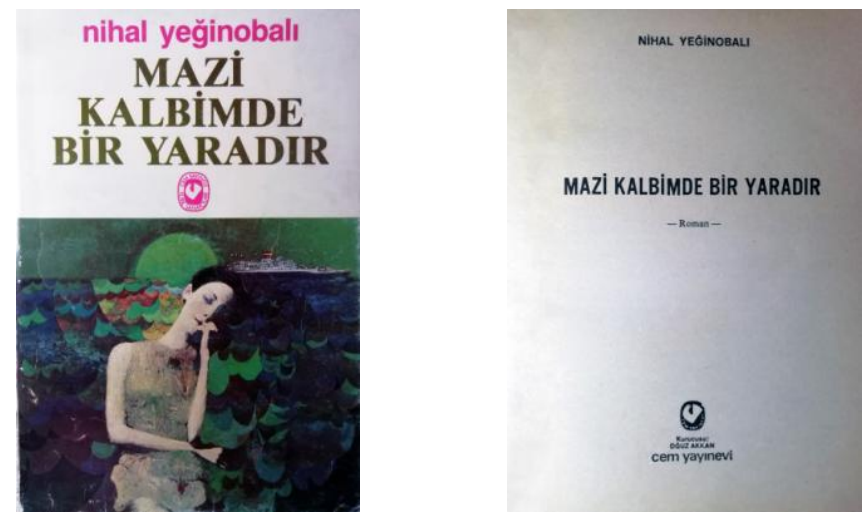

Figure 4. Front cover (left) and inner cover page (right) of Mazi Kalbimde Bir Yaradır (1988) published by Cem.

As an important point, considering the peritextual elements, Mazi Kalbimde Bir Yaradır makes no reference whatsoever to Eflatun $\mathrm{Klz}$, the original novel on which it was actually based. The blurb on the back cover goes even further as to point out that Mazi Kalbimde Bir Yaradır is "the first novel Nihal Yeğinobalı published using her own name," making no mention of the serial novel Eflatun Klz. ${ }^{6}$ This seems to support the thought that considering its presentation and reception, Mazi Kalbimde Bir Yaradır aimed at becoming a replacement of Eflatun $\mathrm{Klz}$, the intralingual translation relations of Mazi Kalbimde Bir Yaradır with Eflatun $\mathrm{Klz}$ - intentionally or not - being in a way concealed. Interestingly enough in this sense, as an epitextual detail, in the aforementioned interview titled "Utandiğım İçin Açıklayamadım" published in Cumhuriyet on 5 June 1988 along with the advertisement of Mazi Kalbimde Bir Yaradır, Nihal Yeğinobalı states:

I thought it was time for me to write using my own name. I wanted to get out from behind the cover of Ewing. I hesitated a little. Particularly in erotic scenes, I thought "I wish I were writing as Ewing". I finally plucked up my courage and showed up with "Mazi Kalbimde Bir Yaradır". (Ersoy, 1988; emphasis in original)

\footnotetext{
${ }^{6}$ Research carried out within the scope of this study shows that apart from Eflatun Klz, Nihal Yeğinobalı has at least one more novel - preceding Mazi Kalbimde Bir Yaradır - published under her own name with the title Kalbimin Sahibi (The owner of my heart) which was serialized in Vatan in 1958 (for the newspaper advertisement of Kalbimin Sahibi, see Appendix). This finding supports the argument of this study that considering their process of existence in physical terms, unless they are later published in book or digital form, serial novels may exist as facts forgotten or made forgotten in a given literary system sometimes resulting in their concealed replacement by other texts.
} 
Eventually, Mazi Kalbimde Bir Yaradır has been circulating as an 'original' in the Turkish literary system since late 1980 's. It would not be incorrect to assume that any reader, who has not read the preceding Eflatun $\mathrm{Klz}$ texts and is not somehow informed that what Mazi Kalbimde Bir Yaradır has become was originally Eflatun Klz, would receive it simply as an 'original' in the customary meaning.

In the light of this translational adventure of Eflatun Klz in the Turkish literary system, the study moves on to rethink the case within the context of Translation Studies through the concepts of pseudo-translation, intralingual translation, self translation, and concealed translation.

\section{Conceptual Discussions}

\subsection{Eflatun $\mathrm{Klz}$ within the Context of Pseudo-Translation}

In Translation Studies literature, it was Anton Popovič who initially pointed to the phenomenon of pseudo-translation, through his concept of "fictitious translation" by which a writer aims to "win a wide public, thus making use of the readers' expectations" (quoted in O'Sullivan 2011, 123). Following Popovič's fictitious translation, Toury $(1995,40)$ defines the concept of pseudo-translation as "texts which have been presented as translations with no corresponding source texts in other languages ever having existed - hence no factual 'transfer operations' and translation relationships." Toury's definition makes it clear that what marks the phenomenon of pseudo-translation is principally the non-existence of a physical source text on which the text presented as a translation depends. In this regard, it can be suggested that the 1964 Eflatun $\mathrm{Klz}$ text, although having been presented as being authored by Vincent Ewing and translated by Nihal Yeğinobal1, does not fit into the concept limitations of pseudotranslation considering the existence of the 1957 serial novel Eflatun $K l z$ as a corresponding physical source text. Furthermore, Carol O'Sullivan's remark also necessitates a reconsideration of Eflatun $\mathrm{K} l z$ within the context of pseudo-translation:

Pseudotranslation functions as a way of importing texts not otherwise acceptable as 'original' writing into a literary system. These texts may be unacceptable as originals either because the material does not conform to existing norms or because the writer of the pseudotranslation lacks sufficient cultural capital to have traction in the target culture. $(2011,123)$ 
In relation to this, it would not be incorrect to suggest that while this was obviously some motivation for Nihal Yeğinobalı in the case of her pseudo-translation Genç Kızlar, the case of Eflatun Klz needs to be further questioned as we already know for sure that before it was presented as an interlingual translation in 1964, Eflatun Klz had already been presented and accepted as an original in the Turkish literary system in 1957, triggering no negative response associated with the acceptability of its eroticized material or the status of Nihal Yeğinobalı as a writer then.

Paolo Rambelli (2009, 209-210) emphasizes that "a pseudotranslation becomes recognized as such only when the overlapping identity of its author and translator is brought to light: until then, the text is simply a translation." Likewise, this study suggests the existence of a corresponding physical source text rules out any text's alleged status of pseudotranslation, and accordingly argues the 1964 Eflatun Klz text can be reframed as a 'pseudo pseudo-translation' or a 'source-text based pseudo-translation' in this sense. ${ }^{7}$ The fact that the source text in our case - the 1957 serial novel - is not a foreign language text as assumed by the concept of pseudo-translation putting emphasis on non-existence of "corresponding source texts in other languages" (Toury 1995, 40; emphasis added), the latter suggestion — 'sourcetext based pseudo-translation' — requires dwelling on the intralingual dimension of translation which tends to be overlooked in concept definitions. This is exactly what Mona Baker (1988, xvii) points out in the preface to the Routledge Encyclopedia of Translation Studies. She puts that "one of the most fascinating things about exploring the history of translation is that it reveals how narrow and restrictive we have been in defining our object of study, even with the most flexible of definitions." In this regard, the following part provides a further rethinking of our present object of study, focusing on the concept of intralingual translation.

\subsection{Eflatun Klz within the Context of Intralingual Translation}

In his paper "On Lingustic Aspects of Translation," Roman Jakobson (1956, 233) mentions three kinds of translation which he defines as follows:

\footnotetext{
7 'Pseudo pseudo-translation' and 'source-text based pseudo-translation' were brought up for discussion in Boy (2018).
} 
- $\quad$ "Intralingual translation or rewording is an interpretation of verbal signs by means of other signs of the same language."

- "Interlingual translation or translation proper is an interpretation of verbal signs by means of some other language."

- "Intersemiotic translation or transmutation is an interpretation of verbal signs by means of signs of nonverbal sign systems."

Baker (1988, xvii) argues that classifications such as Jakobson's triology indeed "alert us to the possibility of such things as intersemiotic and intralingual translation, but we do not make any genuine use of such classifications in our research." At this very point, it may prove useful to accentuate what Baker is critical of is - in one respect - brought about by Jakobson's consideration of interlingual translation as 'translation proper' which makes his classification self-contradicting. Jakobson's classifying translation types but ascribing the qualifier 'proper' only to interlingual translation is regarded as being 'paradox' by Theo Hermans (1997):

If intralingual translation is a form of translation, then in Jakobson's own essay the term "rewording" is a translation of the term "intralingual translation". In this way the first and the third term in the list are both translated intralingually: "intralingual translation" is rendered as "rewording", and "intersemiotic translation" is reworded as "transmutation". But the middle term, "interlingual translation", is not reworded or intralingually translated. It is merely repeated, tautologically restated: this form of translation is translation, "interlingual translation" is "translation proper". The addition of the qualifier "proper" suggests moreover that the other two are not "properly" translation. This, it will be appreciated, undermines the whole exercise of ranging them all three together as so many kinds of translation. (17)

The three Eflatun $K l z$ texts were produced in different periods within the same language with an overlapping plotline but with different highlights on themes and references; namely, in Jakobson's (1956, 233) words, Eflatun Klz was rewritten twice "by means of other signs of the same language" which thus makes the case an illustration of intralingual translation. In textual analysis part of the study following the conceptual discussions, the intralingual translational relations between the three Eflatun $K l z$ texts will be examined based on the source-text postulate, the transfer postulate, and the relationship postulate of Toury's (1995, 33-35) "notion of assumed translation" which can be applied to intralingual translation as well. 
Consideration of Eflatun $\mathrm{Klz}$ as a case of intralingual translation also paves the way for a rethinking within the concept of self translation since the intralingual translation at stake here was performed by Nihal Yeğinobalı - as the writer of the source text - herself.

\subsection{Eflatun Klz within the Context of Self Translation}

In the literature of Translation Studies, a basic definition of the concept of self translation is provided by Popovič as "the translation of an original work into another language by the author himself" (quoted in Montini 2010, 306). Rainier Grutman and Trish Van Bolderen $(2014,323)$ note what stands out as the "single most defining feature" of self translation is the fact that both the source text and the target text are produced by the same physical person. And this physical person enjoys a "doubly privileged status as an author(ity) and as an authorized agent" which "can lead to a reversal, or at least a downplaying, of the hierarchy that normally favors the original over the translation, with neither version taking precedence" (Grutman and Van Bolderen 2014, 324). Furthermore, Grutman draws attention to the fact that "translation scholars themselves have paid little attention to the phenomenon [of self translation], perhaps because they thought it to be more akin to bilingualism than to translation proper" (quoted in Montini 2010, 306).

What particularly attracts attention considering these definitions and discussions in the literature of Translation Studies regarding the concept of self translation is again the fact that they deal with the issue centering upon only the interlingual dimension. This can be linked to the ascribed status of interlingual translation as the 'proper' type of translation by Jakobson in his aforementioned 1959 tripartite typology (Canlı 2018, 294). Depending on the concepts of 'intr-auto-translauthor' ${ }^{\prime 8}$ and "intr-auto-translation" (Canlı 2018, 294), this study argues that the case of Eflatun $\mathrm{Klz}$ can be regarded as an example of 'intralingual self translation' in the Turkish literary system. Taking the rethinking a step further, on the grounds that the intralingual translational relations of the three texts are in a way 'concealed' as one may

\footnotetext{
${ }^{8}$ The concept of "intr-auto-translauthor" is suggested by Gülsüm Canlı in her ongoing PhD dissertation entitled "William Faulkner'ın Sanctuary Adlı Romanının Kaynak ve Erek Dizgedeki Çeviri Serüveni: Diliçi Çeviri, Özçeviri, Yeniden Çeviri ve Dolaylı Çeviri Kavramları Işı̆̆ında Bir İnceleme" (The translational adventure of William Faulkner's Sanctuary in source and target systems: An analysis in the light of intralingual translation, self-translation, retranslation and indirect translation) for a general sketch of which, Canlı and Karadağ (2017) can be consulted.
} 
observe from the accompanying peritextual elements, consideration of Eflatun Klz within the context of concealed translation may also prove useful in terms of the principal aim of this study.

\subsection{Eflatun Klz within the Context of Concealed Translation}

The concept of concealed translation refers to those texts presented and received as indigenous works in a target literary system in spite of actually having been translated themselves. In this context, what characterizes the concept of concealed translation is the replacement of the source text by the target text, which Toury (1995) explains as follows:

Knowledge of the existence of a text in another language and culture, which a targetlanguage text is taken to have replaced, may also serve as a trigger for adopting the assumption that that text is a translation. This last possibility is of paramount heuristic importance for cultures, or historical periods, where translations exist as concealed facts - whether it is only the presentation of a text as being of a derived nature which is not customary or whether the very distinction between translations and nontranslations is not culturally functional and is hence blurred. (70-71)

By definition, the concept of concealed translation points to the existence of a source text "in another language and culture" as stressed by Toury, as well as to the existence of the related source text's real author both of which are regardless of reason or purpose intentionally hidden in the target system by the physical pseudo-writer and other actors involved, if any.

Moving back to the translational adventure of Eflatun $\mathrm{Klz}$, in which Nihal Yeğinobalı performed the intralingual translation of her own once forgotten 1957 indigenous novel and which was presented as a seemingly interlingual translation in 1964 and finally as an 'original' in 1988, it is apparent that what is observed here does not fit into the concept limitations of concealed translation; however, it can be suggested that it gives way to rethinking the concept of concealed translation, broadening its scope so as to cover intralingual self translational phenomena which may intentionally or unintentionally be kept concealed in a literary and cultural system for any reason. As a result of this concept-oriented rethinking, this study suggests a possible conceptual reframing for the 1964 and the 1988 texts as "concealed intralingual self translation."

In the following part, the study moves on to clarify the intralingual translational relations between the three Eflatun Klz texts based on the source text postulate, the transfer 
postulate and the relationship postulate of Toury's (1995, 33-35) "notion of assumed translation."

\section{Textual Analysis}

According to Toury $(1995,32)$, assumed translations denote "all utterances which are presented or regarded as such [as translations] within the target culture, on no matter what grounds." More specifically, Toury offers the following definition for the "notion of assumed translation":

Any target-culture text for which there are reasons to tentatively posit the existence of another text, in another culture and language, from which it was presumedly derived by transfer operations and to which it is now tied by certain relationships, some of which may be regarded -within that culture- as necessary and/or sufficient. $(1995,35)$

Accordingly, for any text to be regarded as an "assumed translation," he proposes three interconnected postulates as the source-text postulate, the transfer postulate, and the relationship postulate:

Regarding a text as a translation entails the obvious assumption that there is another text, in another culture/language, which has both chronological and logical priority over it: not only has such an assumed text assumedly preceded the one taken to be its translation in time, but it is also presumed to have served as a departure point and basis for the latter. (1995, 33-34)

Important for this study, examining the first postulate, Toury's point of emphasis on the assumption of "another text, in another culture/language" is interpreted by Andrew Chesterman $(1997,62)$ as "normally in another language." In the case of Eflatun Klz, there exists a source text in the same language serving as a basis for the 1964 intralingual translation presented as a seemingly interlingual translation. There, in addition, exist two source texts serving as basis for the 1988 assumedly 'original' text. In this sense, it can be suggested that the source-text postulate can also be applied to intralingual dimension of translation.

Considering the second postulate, Toury $(1995,34)$ notes "the Source-Text Postulate also entails the assumption that the process whereby the assumed translation came into being involved the transference from the assumed source text of certain features that the two now share." Reflecting on the second postulate, an intralingual transfer process can be observed in 
the case of Eflatun Klz, in the sense that while the 1964 text includes foreignization of the context in the very same language particularly through culture-specific items, the 1988 text includes a re-domestication. Hence, it can be suggested that the transfer postulate can be deemed relevant also for intralingual translation.

With regard to the third postulate, Toury (1995) states:

Adopting the assumption that a text is a translation also implies that there are accountable relationships which tie it to its assumed original, an obvious function of that which the two texts allegedly share and which is taken to have been transferred across the cultural-semiotic (and linguistic) border. (35)

Considering the relationship postulate, also based on Chesterman $(1997,62)$ who asking the question "What kinds of intertextual relationships count as translational ones?" introduces the concept of "relevant similarity" as a possible reference point to determine whether or not the relationship postulate is attained, it can be said that in the case of Eflatun $K l z$, the relationship postulate is also fulfilled as "relative similarity" exists between the three texts sharing the same plotline with changes in particular to specific themes and references, bringing about additions and omissions in the same language by Nihal Yeğinobalı herself.

In this light, the three postulates can be considered as relevant not only to interlingual translation but also to intralingual translation. And, in the case of Eflatun Klz, which is suggested to be framed as a "concealed intralingual self translation" in this study, we can make mention of the existence of a source text in the same language, an intralingual transfer between the three texts, and intertextual relationships or relative similarities interconnecting these three texts. Taking this as a basis, the attempt of this study to explain the intralingual translational relations between the three Eflatun Klz texts in this part focuses particularly on the 'eflatun kız' theme, the 'mazi kalbimde bir yaradır' theme, and culture-specific items and extratextual references. ${ }^{9}$

\subsection{The 'Eflatun Kiz' Theme}

Giving the novel its name, 'eflatun k1z', which implies a woman's virginity belonging to a particular man by whom she is deflowered, is the main theme around which the story revolves in the 1957 source text, as well as in the 1964 intralingual translation. As can be

\footnotetext{
${ }^{9}$ All translations of the excerpts and the emphases therein are my own, unless otherwise indicated.
} 
observed from the corresponding excerpts in table 1 , in which the female protagonist asks the man - who later becomes her husband - the color of her name, in the 1964 text the theme was preserved while in the 1988 text it was completely removed with the man's answering the little girl's question as "I don't know," bringing about the omission of the 'eflatun k1z' theme from the whole text.

Table 1. The 'eflatun k1z' theme - Example 1

\begin{tabular}{|c|c|c|}
\hline Eflatun Kız (1957) & Eflatun Kız (1964) & $\begin{array}{l}\text { Mazi Kalbimde Bir } \\
\text { Yaradır (1988) }\end{array}$ \\
\hline $\begin{array}{l}\text { "Benim ismim ne renk?" } \\
\text { diye sordu. "Yelda ne } \\
\text { renk?" } \\
\text { Genç adam derhal: } \\
\text { "Eflâtun." diye cevap } \\
\text { verdi. "Yer yer mora çalan } \\
\text { bir eflâtun. Benim en } \\
\text { sevdiğim renk." } \\
\text {.. } \\
\text { "Eflâtun sana her halde } \\
\text { yakışır. Ve inşallah } \\
\text { büyüdü̆ğun zaman da } \\
\text { isminin rengine lâyık bir } \\
\text { kız olursun." } \\
\text { "Nasıl olmak lâzım?" } \\
\text { Yabancı, "İhtiraslı hem de } \\
\text { sakin." diye cevap verdi. } \\
\text { "İhtirasın rengi mordur } \\
\text { ama zekânın, vekarın, } \\
\text { hayallerin 1şığı vurunca } \\
\text { eflâtun olur. Eflâtun } \\
\text { lüzumunda gene mor } \\
\text { olmağa her an hazırdır. } \\
\text { Eflâtun kızlara bayılırım } \\
\text { ben, Yelda. Ama } \\
\text { dünyada o kadar az } \\
\text { eflâtun kız var ki!" } \\
\text { Yelda, onun sözlerinden } \\
\text { hiç bir şey anlamıyordu. } \\
\text { Ama sesindeki iştiyakı } \\
\text { hissettiği için, } \\
\text { "Ben eflâtun bir kız } \\
\text { olacağım." dedi. } \\
\text { Ve genç adam onu gene }\end{array}$ & $\begin{array}{l}\text { "Benim ismim ne renk?" } \\
\text { diye sordu. "Antonia ne } \\
\text { renk?" } \\
\text { Genç adam, "Eflâtun," } \\
\text { diye cevap verdi. "Mora } \\
\text { bakan bir eflâtun. Benim } \\
\text { en sevdiğim renk!" } \\
\text {.. } \\
\text { Eflâtun sana kim bilir ne } \\
\text { kadar yaraşır. İnşallah } \\
\text { büyüdüğ̈ü zaman da } \\
\text { tam bir Eflâtun kız } \\
\text { olursun, Tonia." } \\
\text { Antonia içi titriyerek, } \\
\text { "Nasıl olur Eflâtun kızlar?" } \\
\text { diye sordu. (36) } \\
\text { "Hem ihtiraslı hem de } \\
\text { asude! İhtirasın rengi } \\
\text { mordur. Morun üstüne } \\
\text { zekânın, vekarın ve } \\
\text { hayallerin ışı̆̆ vurunca } \\
\text { eflâtuna döner. Ama } \\
\text { Eflâtun gene her gerektiği } \\
\text { an mor olmağa hazırdır. } \\
\text { Eflâtun kızlara bayılırım } \\
\text { ben, Tonia'm. Ama } \\
\text { dünyada o kadar az } \\
\text { Eflâtun kız var ki!" } \\
\text { Antonia onun sözlerinden } \\
\text { hiç bir şey anlamıyordu. } \\
\text { Ama sesindeki iştiyak1, } \\
\text { özlemi ta içinde } \\
\text { hissetmişti. Onun için } \\
\text { erkeğin elini tuttu ve }\end{array}$ & $\begin{array}{l}\text { "Lamia'nın rengi } \\
\text { neymiş?" } \\
\text { Ali, "Bilemiyeceğim," } \\
\text { diye güldü. (48) }\end{array}$ \\
\hline
\end{tabular}




\begin{tabular}{|c|c|c|}
\hline $\begin{array}{l}\text { bağrına bastı: "İsminle çok } \\
\text { yaşa!" (Serial No. 16) }\end{array}$ & $\begin{array}{l}\text { ciddiyetle, } \\
\text { "Ben Eflâtun kız } \\
\text { olacağım," dedi. } \\
\text { "Mersi, Tonia." (36-37) }\end{array}$ & \\
\hline $\begin{array}{l}\text { "What colour is my } \\
\text { name?" she asked. } \\
\text { "What colour is Yelda?" } \\
\text { "Lilac." the young man } \\
\text { immediately replied. "A } \\
\text { lilac verging partly on } \\
\text { purple. My favourite } \\
\text { colour." } \\
\text {. . } \\
\text { "Lilac would surely fit } \\
\text { you. And I hope you } \\
\text { would be a girl worthy of } \\
\text { the colour of your name } \\
\text { when you grow up." } \\
\text { "How is one supposed to } \\
\text { be?" } \\
\text { "Passionate and also } \\
\text { calm." the stranger replied. } \\
\text { "The colour of passion is } \\
\text { purple but it turns lilac } \\
\text { with the light of } \\
\text { intelligence, dignity, } \\
\text { dreams. Lilac is always } \\
\text { ready to turn purple again } \\
\text { when required. I adore } \\
\text { lilac girls, Yelda. But } \\
\text { there are so few lilac } \\
\text { girls in the world!" } \\
\text { Yelda didn't understand } \\
\text { anything from his words. } \\
\text { But because she felt the } \\
\text { desire in his voice, } \\
\text { "I will be a lilac girl." } \\
\text { she said. } \\
\text { And the young man } \\
\text { embraced her against his } \\
\text { chest again: "Long live } \\
\text { with your name!" (Serial } \\
\text { No. 16.) }\end{array}$ & $\begin{array}{l}\text { "What colour is my } \\
\text { name?" she asked. } \\
\text { "What colour is } \\
\text { Antonia?" } \\
\text { "Lilac." the young man } \\
\text { replied. "A lilac verging on } \\
\text { purple. My favourite } \\
\text { colour!" } \\
\text {.. } \\
\text { "Who knows how much } \\
\text { lilac would fit you. I hope } \\
\text { you would be a total Lilac } \\
\text { girl when you grow up, } \\
\text { Tonia." } \\
\text { "What are Lilac girls like?" } \\
\text { Antonia asked caringly. } \\
\text { (36) } \\
\text { "Both passionate and calm! } \\
\text { The colour of passion is } \\
\text { purple. Purple turns lilac } \\
\text { with the light of } \\
\text { intelligence, dignity and } \\
\text { dreams. But Lilac is still } \\
\text { ready to turn purple } \\
\text { whenever required. I adore } \\
\text { Lilac girls, my Tonia. But } \\
\text { there are so few Lilac } \\
\text { girls in the world!" } \\
\text { Antonia didn't understand } \\
\text { anything from his words. } \\
\text { But she deeply inside felt } \\
\text { the desire, the longing in } \\
\text { his voice. So, she held the } \\
\text { man's hand and earnestly } \\
\text { said, } \\
\text { "I will be a Lilac girl." } \\
\text { "Merci, Tonia." (36-37) }\end{array}$ & $\begin{array}{l}\text { "What colour is Lamia?" } \\
\text { "I don't know," Ali } \\
\text { laughed. (48) }\end{array}$ \\
\hline
\end{tabular}


While the exclusion of the 'eflatun k1z' theme from the 1988 text can also be observed from the examples in table 2, it is clear that this exclusion did not result in the omission of the 'eflatun k1z' related parts as a whole from the text.

Table 2. The "eflatun k1z" theme - Example 2

\begin{tabular}{|c|c|c|}
\hline Eflatun Kız (1957) & Eflatun Kız (1964) & $\begin{array}{l}\text { Mazi Kalbimde Bir } \\
\text { Yaradır (1988) }\end{array}$ \\
\hline $\begin{array}{l}\text { "Eflâtunun mor kesildiği } \\
\text { andayız Yelda," diye } \\
\text { fısıldadı. "Biliyorsun değil } \\
\text { mi? Bunu sen de } \\
\text { istiyorsun, değil mi? Ne } \\
\text { yaptığının farkındasın } \\
\text { değil mi, Yelda?" (Serial } \\
\text { No. 50) } \\
\text { "Ben olacaktım," } \\
\text { diyordu. "Eflâtunu mora } \\
\text { döndüren ben } \\
\text { olacaktım... Kendini ona } \\
\text { verecek ne vardı? Beni } \\
\text { neden beklemedin?" } \\
\text {.. } \\
\text { "Seni benden başkası nasıl } \\
\text { sever?" diye sordu. "Bu } \\
\text { dudakları benden başkası } \\
\text { nasıl öper?" } \\
\text { Eğildi, dudaklarını kızın } \\
\text { yarı açık ağzına bastırdı. } \\
\text { Sanki onu öperek } \\
\text { öldürecekti. } \\
\text { "Bu vücudü benden } \\
\text { başkası nasıl okşar? Seni } \\
\text { çıplak, benden başkası } \\
\text { nasıl görür?" (Serial No. } \\
\text { 51) }\end{array}$ & $\begin{array}{l}\text { "Eflâtunun mor kesildiği } \\
\text { andayız, Antonia," diye } \\
\text { fısıldadı. "Biliyorsun, değil } \\
\text { mi? Bunu sen de } \\
\text { istiyorsun, değil mi? Ne } \\
\text { yaptığının farkındasın, } \\
\text { değil mi, Tonia?" (146) } \\
\text { "Ben olacaktım," } \\
\text { diyordu. "Eflâtunu mora } \\
\text { döndüren ben olacaktım. } \\
\text { Kendini ona verecek ne } \\
\text { vardı? Beni neden } \\
\text { beklemedin?" } \\
\text {.. } \\
\text { "Seni benden başkası nasıl } \\
\text { sever? Bu dudakları } \\
\text { benden başkası nasıl öper?" } \\
\text { Eğildi, dudaklarını kızın } \\
\text { yarı açık ağzına bastırdı. } \\
\text { Sanki onu öperek } \\
\text { öldürecekti. } \\
\text { "Bu vücudü benden başkası } \\
\text { nasıl okşar? Seni böyle } \\
\text { çıplak, benden başkası } \\
\text { nasıl görür?" (147) }\end{array}$ & $\begin{array}{l}\text { "Sen de istiyorsun, değil } \\
\text { mi Lamia?" diye Ali onu } \\
\text { öpmeye eğildi. "Ne } \\
\text { yaptığını biliyorsun, değil } \\
\text { mi? diye öpüşlerinin } \\
\text { arasından sordu." (187) } \\
\text { "Ben olacaktım. Ben } \\
\text { olmalıydım. Ama odaya } \\
\text { girdin, bana baktın, beni } \\
\text { görmedin bile. Turan'la } \\
\text { sen... daha o zamandan } \\
\text { mı?" } \\
\text {.. } \\
\text { "Seni benden başkası nasıl } \\
\text { sever?" diye sordu. "Bu } \\
\text { dudakları benden başkası } \\
\text { nasıl öper?" Dudaklarını } \\
\text { kızın yarı aralık duran } \\
\text { ağzına hırsla, sanki kinle } \\
\text { bastırdı. Onu öperek } \\
\text { öldürecekti sanki. "Bu } \\
\text { vücudu benden başkası } \\
\text { nasıl okşar?" dedi onu } \\
\text { hoyratlaşmış ellerle } \\
\text { hırpalayarak. "Seni çıplak, } \\
\text { benden başkası nasıl } \\
\text { görür?" (188) }\end{array}$ \\
\hline $\begin{array}{l}\text { "We are at the moment } \\
\text { when lilac turns purple } \\
\text { Yelda," he whispered. } \\
\text { "You know, don't you? } \\
\text { You also want this, don't } \\
\text { you? You are aware of } \\
\text { what you are doing, aren't } \\
\text { you, Yelda?" (Serial No. }\end{array}$ & $\begin{array}{l}\text { "We are at the moment } \\
\text { when lilac turns purple, } \\
\text { Antonia," he whispered. } \\
\text { "You know, don't you? } \\
\text { You also want this, don't } \\
\text { you? You are aware of } \\
\text { what you are doing, aren't }\end{array}$ & $\begin{array}{l}\text { "You also want, don't you, } \\
\text { Lamia?" Ali bent to kiss } \\
\text { her. "You know what you } \\
\text { are doing, don't you?" he } \\
\text { asked through his kisses. } \\
\text { (187) } \\
\text { "I was to be the one. I }\end{array}$ \\
\hline
\end{tabular}




\begin{tabular}{|c|c|c|}
\hline $\begin{array}{l}\text { "I } \\
\text { was } \\
\text { the } \\
\text { pur } \\
\text { did } \\
\text { him } \\
\text { for } n\end{array}$ & $\begin{array}{l}\text { you, Tonia?" (146) } \\
\text { "I was to be the one," he } \\
\text { was saying. "I was to be } \\
\text { the one turning lilac into } \\
\text { purple... "Why on earth } \\
\text { you did you give yourself } \\
\text { to him? Why didn't you } \\
\text { wait for me?" } \\
\text {.. } \\
\text { "How can someone other } \\
\text { than me love you? How } \\
\text { can someone other than me } \\
\text { kiss these lips?" } \\
\text { He bent, pressed his lips to } \\
\text { the girl's half open mouth. } \\
\text { It was like he was going to } \\
\text { kill her by kissing. } \\
\text { "How can someone other } \\
\text { than me caress this body? } \\
\text { How can someone other } \\
\text { than me see you naked like } \\
\text { this?" (147) }\end{array}$ & $\begin{array}{l}\text { should have been the one. } \\
\text { But you entered the room, } \\
\text { looked at me, you didn't } \\
\text { even see me. Turan and } \\
\text { you... Is it since then?" } \\
\text {.. } \\
\text { "How can someone other } \\
\text { than me love you?" he } \\
\text { asked. "How can someone } \\
\text { other than me kiss these } \\
\text { lips?" He pressed his lips } \\
\text { to the girl's half open } \\
\text { mouth with greed, as if } \\
\text { with grudge. It was like he } \\
\text { was going to kill her by } \\
\text { kissing. "How can } \\
\text { someone other than me } \\
\text { caress this body?" he said, } \\
\text { mauling her with his now } \\
\text { rough hands. "How can } \\
\text { someone other than me see } \\
\text { you naked?" (188) }\end{array}$ \\
\hline
\end{tabular}

\subsection{The 'Mazi Kalbimde Bir Yaradır' Theme}

An additional reference in the 1957 source text was built on the theme 'mazi kalbimde bir yaradır' which later gave the 1988 novel its name. This theme was originally mentioned in the 1957 serial novel with explicit reference to the first Turkish tango "Mazi" (The past) which was written by Necdet Rüştü Efe Tara, composed by Necip Celâl Andel in 1928, and first performed by Seyyan (Oskay) Hanım in 1932. While the tone created in the source text by reference to a tango from the past was kept in the 1964 text in contextual terms, it can be observed that the referenced tango song along with its lyrics was replaced by means of foreignization within the same language so as to give the impression that there exists an interlingual transfer. Considering the 1988 text, it can be said that the story much more profoundly centers around the 'mazi kalbimde bir yaradir' theme. Examples from the passages where the related tango theme appears within the texts for the very first time are shown in table 3 . 
Table 3. The 'mazi kalbimde bir yaradır' theme - Example 1

\begin{tabular}{|c|c|c|}
\hline Eflatun Kız (1957) & Eflatun Kız (1964) & $\begin{array}{c}\text { Mazi Kalbimde Bir } \\
\text { Yaradır (1988) }\end{array}$ \\
\hline $\begin{array}{l}\text { Çalgı daha onlar evden } \\
\text { çıkmadan başladı. Davulun } \\
\text { temposu durgun ve sıcak } \\
\text { hava içinde yaz gecesinin } \\
\text { kalbi gibi vuruyor, bütün } \\
\text { şehre nağme nağme hayat } \\
\text { yayıyordu. Bu, Yeşilceden } \\
\text { başka yerlerde belki de } \\
\text { çalmaz olmuş, unutulmuş } \\
\text { bir eski tangoydu ki onlara } \\
\text { çocukluklarını hatırlattığı } \\
\text { için pek severlerdi: } \\
\text { "Mazi kalbimde bir } \\
\text { yaradır, bahtım } \\
\text { saçlarımdan karadır..." } \\
\text { (Serial No. 23) }\end{array}$ & $\begin{array}{l}\text { Çalgı daha onlar evden } \\
\text { çıkmadan başladı. Davulun } \\
\text { temposu durgun ve sıcak } \\
\text { hava içinde yaz gecesinin } \\
\text { kalbi gibi vuruyor, bütün } \\
\text { şehre nağme, nağme hayat } \\
\text { yayıyordu. Bu, } \\
\text { Orleana'dan başka yerlerde } \\
\text { belki de çalmaz olmuş, } \\
\text { unutulmuş çok eski bir } \\
\text { tangoydu ki onlara } \\
\text { çocukluklarını hatırlattığı } \\
\text { için pek severlerdi: } \\
\text { "Söyle bana, seviyor } \\
\text { musun ah, söyle bana, } \\
\text { söyle gülüm } \\
\text { Arjantina..." (69) }\end{array}$ & $\begin{array}{l}\text { Uzunca bir ara veren } \\
\text { çalgıcılar yerlerine geçip } \\
\text { akorda başlamışlardı. Biraz } \\
\text { sonra gene eski bir } \\
\text { tangonun notaları çam } \\
\text { dallarının arasına } \\
\text { saçılmaya başladı: "Mazi } \\
\text { kalbimde bir yaradır, } \\
\text { bahtım saçlarından } \\
\text { karadır..." (96; italics in } \\
\text { original) }\end{array}$ \\
\hline $\begin{array}{l}\text { The music started before } \\
\text { they left home. The drum } \\
\text { was beating like the heart } \\
\text { of the summer night in the } \\
\text { still and hot air, spreading } \\
\text { life in tunes to the whole } \\
\text { city. This was a forgotten, } \\
\text { old tango which was } \\
\text { probably not played any } \\
\text { more in places other than } \\
\text { Yeşilce, and they liked it } \\
\text { very much as it reminded } \\
\text { them of their childhood: } \\
\text { "The past is a wound in } \\
\text { my heart, my fortune is } \\
\text { darker than my hair..." } \\
\text { (Serial No. 23) }\end{array}$ & $\begin{array}{l}\text { The music started before } \\
\text { they left home. The drum } \\
\text { was beating like the heart } \\
\text { of the summer night in the } \\
\text { still and hot air, spreading } \\
\text { life in tunes to the whole } \\
\text { city. This was a forgotten, } \\
\text { very old tango which was } \\
\text { probably not played any } \\
\text { more in places other than } \\
\text { Orleana, and they liked it } \\
\text { very much as it reminded } \\
\text { them of their childhood: } \\
\text { "Tell me, do you love oh, } \\
\text { tell me, tell my rose } \\
\text { Argentina..." (69) }\end{array}$ & $\begin{array}{l}\text { The players who had a } \\
\text { long break had taken their } \\
\text { places and started tuning } \\
\text { their instruments. After a } \\
\text { while, the notes of an old } \\
\text { tango again started to fly } \\
\text { into pine branches: "The } \\
\text { past is a wound in my } \\
\text { heart, my fortune is } \\
\text { darker than my hair..." } \\
\text { (96; italics in original) }\end{array}$ \\
\hline
\end{tabular}

This theme is also crucial in the sense that it marks the very end of the source text, as well as that of the 1988 text in both of which it remains a mystery whether the woman goes back to her husband after a farewell with the man, her past love by whom she was deflowered. In the end of the 1964 text, on the other hand, by addition of a new paragraph, it is made quite clear that she goes back to her husband, as can be seen in table 4 . 
Table 4. The 'mazi kalbimde bir yaradır' theme - Example 2

\begin{tabular}{|c|c|c|}
\hline Eflatun Kız (1957) & Eflatun Kız (1964) & $\begin{array}{l}\text { Mazi Kalbimde Bir } \\
\text { Yaradır (1988) }\end{array}$ \\
\hline $\begin{array}{l}\text { Yelda durmadan akan } \\
\text { gözyaşlarının arasından } \\
\text { onu silik, beyazlı bir hayal } \\
\text { olarak görebiliyordu. Elini } \\
\text { kaldırıp salladı. } \\
\text { Yeşilce gecesini bir eski } \\
\text { aşk şarkısı doldurmuştu: } \\
\text {... Mazi kalbimde bir } \\
\text { yaradır, bahtım } \\
\text { saçlarından karadır... } \\
\text { Beni zaman zaman } \\
\text { ağlatan işte bu hazin } \\
\text { hatıradır. (Serial No. 92) }\end{array}$ & $\begin{array}{l}\text { Antonia durmadan akan } \\
\text { göz yaşlarının arasından } \\
\text { onu silik, beyazlı bir hayâl } \\
\text { olarak görebiliyordu. } \\
\text { Robin köşeyi dönerken } \\
\text { durup arkasına baktı, elini } \\
\text { salladı. Antonia da elini } \\
\text { kaldırıp salladı. } \\
\text { Orleana gecesini bir eski, } \\
\text { unutulmuş aşk şarkısı } \\
\text { doldurmuştu: } \\
\text { Söyle bana, seviyor } \\
\text { musun ah, söyle bana... } \\
\text { Antonia, "Seviyorum, } \\
\text { Robin," diye hıçkırdı, } \\
\text { "Ömrümün sonuna } \\
\text { kadar da seveceğim!" } \\
\text { Sonra göz yaşlarını sildi } \\
\text { ve geriye dönüp eve, } \\
\text { kocasına doğru } \\
\text { yürümeğe başladı. (254) }\end{array}$ & $\begin{array}{l}\text { Turan köşeye varınca } \\
\text { durup arkasına baktı, elini } \\
\text { salladı. Lamia durmadan } \\
\text { akan, yüzünü, boynunu } \\
\text { 1slatan göz yaşları } \\
\text { arasından onu silik, uçuk } \\
\text { bir hayal olarak } \\
\text { görebiliyordu. Elini } \\
\text { kaldırıp salladı. } \\
\text { Yeşilce gecesini bir eski } \\
\text { aşk şarkısı doldurmuştu: } \\
\text { Mazi kalbimde bir } \\
\text { yaradır, bahtım } \\
\text { saçlarından karadır. Beni } \\
\text { zaman zaman ağlatan, işte } \\
\text { bu hazin hatıradır... (326; } \\
\text { italics in original) }\end{array}$ \\
\hline $\begin{array}{l}\text { Through her endlessly } \\
\text { flowing tears, Yelda could } \\
\text { see him as a shadowy, } \\
\text { whity dream. She raised } \\
\text { and waved her hand. } \\
\text { Yeşilce night was filled } \\
\text { with an old love song: } \\
\text {...The past is a wound in } \\
\text { my heart, my fortune is } \\
\text { darker than my hair... } \\
\text { What makes me cry from } \\
\text { time to time is this sad } \\
\text { memory. (Serial No. 92) }\end{array}$ & $\begin{array}{l}\text { Through her endlessly } \\
\text { flowing tears, Antonia } \\
\text { could see him as a } \\
\text { shadowy, whity dream. } \\
\text { While turning the corner, } \\
\text { Robin stopped and looked } \\
\text { back, waved his hand. } \\
\text { Antonia also raised and } \\
\text { waved her hand. } \\
\text { Orleana night was filled } \\
\text { with an old, forgotten } \\
\text { love song: } \\
\text { Tell me, do you love oh, } \\
\text { tell me... } \\
\text { "I love, Robin," Antonia } \\
\text { sobbed, "And I will love } \\
\text { till the end of my life!" } \\
\text { Then, she wiped her } \\
\text { tears, turned back and } \\
\text { started walking towards } \\
\text { home, to her husband. } \\
\text { (254) }\end{array}$ & $\begin{array}{l}\text { When he arrived at the } \\
\text { corner, Turan stopped and } \\
\text { looked back, waved his } \\
\text { hand. Through her } \\
\text { endlessly flowing tears, } \\
\text { wetting her face, her neck, } \\
\text { Lamia could see him as a } \\
\text { shadowy, pale dream. She } \\
\text { raised and waved her hand. } \\
\text { Yeşilce night was filled } \\
\text { with an old love song: } \\
\text { The past is a wound in my } \\
\text { heart, my fortune is } \\
\text { darker than my hair. } \\
\text { What makes me cry from } \\
\text { time to time is this sad } \\
\text { memory... ( } 326 \text {; italics in } \\
\text { original) }\end{array}$ \\
\hline
\end{tabular}




\subsection{Culture-Specific Items and Extratextual References}

It can be implied in the case of Eflatun $\mathrm{Klz}$ that foreignization or domestication strategies may be also relevant to intralingual translation particularly considering culturespecific items such as food and drink. In this context, it is observed that while the food names common to Turkish cuisine in the source text are foreignized within the same language so as to make the existence of an originally English language context felt in the 1964 text. As can be understood from the examples in table 5, the point here is that what becomes, for instance, "deniz kabukları içinde ekmek ufağı ve domatesle firınlanmış olan yengeç etleri" (crabmeat baked in seashells with bread crumbs and tomato) is originally "enginarlı bakla" (artichoke with broad beans) in the source text as one of the well-known tastes of the Turkish food culture. Similarly, "sarmısaklı mercimek çorbası" (lentil soup with garlic) in the source text is intralingually foreignized as "bamyalı karides çorbası" (okra soup with shrimp) in the 1964 text. The 1988 text, in this regard, generally follows the 1957 source text closer with small changes such as in the examples of "enginarlı iç bakla" (artichoke with shelled broad beans) and "naneli yeşil mercimek çorbası" (green lentil soup with mint).

Table 5. Food as culture-specific items

\begin{tabular}{|c|c|c|}
\hline Eflatun Kız (1957) & Eflatun Kız (1964) & $\begin{array}{l}\text { Mazi Kalbimde Bir } \\
\text { Yaradır (1988) }\end{array}$ \\
\hline $\begin{array}{l}\text { Enginarlı bakla sofraya } \\
\text { geldiği zaman Bekir, } \\
\text { "Kuzum Handan, hadi } \\
\text { bana biraz daha badem } \\
\text { kavuruver," dedi. (Serial } \\
\text { No. 64) }\end{array}$ & $\begin{array}{l}\text { Deniz kabukları içinde } \\
\text { ekmek ufağı ve } \\
\text { domatesle firınlanmış } \\
\text { olan yengeç etleri sofraya } \\
\text { gelince kocası Lili'ye } \\
\text { seslendi: "Kuzum Lili, } \\
\text { bana biraz daha kereviz } \\
\text { sapı getirir misin?" (177) }\end{array}$ & $\begin{array}{l}\text { Enginarlı iç bakla sofraya } \\
\text { geldiği zaman Bekir, } \\
\text { "Kuzum, Süsi, hadi bana } \\
\text { biraz badem kavuruver," } \\
\text { dedi. (219) }\end{array}$ \\
\hline $\begin{array}{l}\text { When artichoke with } \\
\text { broad beans was brought } \\
\text { to the table, Bekir said, } \\
\text { "Handan, my dear, roast } \\
\text { some more almonds for } \\
\text { me." (Serial No. 64) }\end{array}$ & $\begin{array}{l}\text { When crabmeat baked in } \\
\text { seashells with bread } \\
\text { crumbs and tomato was } \\
\text { brought to the table, her } \\
\text { husband called out to Lili: } \\
\text { "Lili, my dear, could you } \\
\text { bring me some more } \\
\text { celery ribs?" (177) }\end{array}$ & $\begin{array}{l}\text { When artichoke with } \\
\text { shelled broad beans was } \\
\text { brought to the table, Bekir } \\
\text { said, "Süsi, my dear, roast } \\
\text { some more almonds for } \\
\text { me." (219) }\end{array}$ \\
\hline $\begin{array}{l}\text { "Bu çorbayı mahsus senin } \\
\text { için yaptırdım, yavrum," }\end{array}$ & $\begin{array}{l}\text { "Bu çorbayı mahsus senin } \\
\text { için yaptırdım, güzelim," }\end{array}$ & $\begin{array}{l}\text { "Bu çorbayı mahsus senin } \\
\text { için yaptırdım, Lamia'm," }\end{array}$ \\
\hline
\end{tabular}




\begin{tabular}{|c|c|c|}
\hline $\begin{array}{l}\text { dedi. . . . "Senin } \\
\text { sarmısaklı mercimek } \\
\text { çorbasını sevdiğini } \\
\text { bilirim." (Serial No. 13) }\end{array}$ & $\begin{array}{l}\text { dedi. . . . "Senin bamyalı } \\
\text { karides çorbasını nasıl } \\
\text { sevdiğini bilirim çünkü." } \\
\text { (26) }\end{array}$ & $\begin{array}{l}\text { dedi. . . . "Senin bu naneli } \\
\text { yeşil mercimek çorbasını } \\
\text { en çok sevdiğini bilirim } \\
\text { de." (39) }\end{array}$ \\
\hline $\begin{array}{l}\text { "I had this soup cooked } \\
\text { specially for you, my } \\
\text { little," she said. . . . "I } \\
\text { know you like lentil soup } \\
\text { with garlic." (Serial No. } \\
\text { 13) }\end{array}$ & $\begin{array}{l}\text { "I had this soup cooked } \\
\text { specially for you, my } \\
\text { beautiful," she said. . . } \\
\text { "Because I know how } \\
\text { much you like okra soup } \\
\text { with shrimp." (26) }\end{array}$ & $\begin{array}{l}\text { "I had this soup cooked } \\
\text { specially for you, my } \\
\text { Lamia," she said. . . . "I } \\
\text { know you most like this } \\
\text { green lentil soup with } \\
\text { mint." (39) }\end{array}$ \\
\hline
\end{tabular}

Table 6 shows a clear example of an additional important point to be emphasized with regard to the intralingual translational relations in the case of Eflatun Klz. This point is particularly marked in the 1988 text in the addition of obvious references to Mustafa Kemal Atatürk, the founder of the Republic of Turkey, as implied in the text for the very first time with the addition of "Kemal" to the sentence which included only "Mustafa" in the source text.

Table 6. Extratextual reference to Mustafa Kemal Atatürk

\begin{tabular}{|c|c|c|}
\hline Eflatun Kız (1957) & Eflatun Kız (1964) & $\begin{array}{l}\text { Mazi Kalbimde Bir } \\
\text { Yaradır (1988) }\end{array}$ \\
\hline $\begin{array}{l}\text { Yelda, "Ali ismi iyi isim," } \\
\text { dedi. "Ama ben en çok } \\
\text { Mustafayı severim. } \\
\text { Büyüyünce çocuğum } \\
\text { olduğu zaman adını } \\
\text { Mustafa koyacağım. İkinci } \\
\text { bir oğlum olursa belki Ali } \\
\text { koyarım." (Serial No. 16) }\end{array}$ & $\begin{array}{l}\text { Kız, "Mark iyi isim," dedi. } \\
\text { "Büyüyüp çocuğum olunca } \\
\text { ilk oğlumun adına } \\
\text { Michael diyeceğim, çünkü } \\
\text { babamın ismi. İkinci } \\
\text { oğlumun adına da siz izin } \\
\text { verirseniz Mark derim." } \\
\text { (37) }\end{array}$ & $\begin{array}{l}\text { Lamia başını onun dizine } \\
\text { bırakarak, "Ali iyi isim," } \\
\text { dedi. "Ama ben erkek } \\
\text { isimlerinden en çok } \\
\text { Mustafa'yı seviyorum. } \\
\text { Sonra da Kemal..." (49) }\end{array}$ \\
\hline $\begin{array}{l}\text { "The name Ali is a nice } \\
\text { name," Yelda said. "But I } \\
\text { like Mustafa the most. } \\
\text { When I have a child when } \\
\text { I grow up, I will name him } \\
\text { Mustafa. If I have a second } \\
\text { son, I will maybe name } \\
\text { him Ali." (Serial No. 16) }\end{array}$ & $\begin{array}{l}\text { "Mark is a nice name," the } \\
\text { girl said. "When I grow up } \\
\text { and have a child, I will } \\
\text { name my first son Michael } \\
\text { because it's my father's } \\
\text { name. And I will name my } \\
\text { second son Mark, if you } \\
\text { allow." (37) }\end{array}$ & $\begin{array}{l}\text { "Ali is a nice name," } \\
\text { Lamia said, leaving her } \\
\text { head on his knee. "But } \\
\text { among boys' names, I like } \\
\text { Mustafa the most. And } \\
\text { then Kemal..." (49) }\end{array}$ \\
\hline
\end{tabular}

In this regard, the following excerpt from Mazi Kalbimde Bir Yaradır (1988) constitutes one of the most prominent examples of reference to Atatürk and the Republic where Nihal Yeğinobalı clearly reflects her ideological stance which can also be considered as 
an intervention encouraged by her more acknowledged status in the Turkish literary system by the late 1980 's.

Hele Ali'nin Gazi'yi de tanıdığı, bir yaz günü Yalova'daki köşke yapılan bir ziyaret sırasında onunla tokalaştığı anlaşılınca hepsi çılgına döndüler. Süsi Gazi'nin göz renginin tam tonunu öğrenmek istiyor, Lütfiye Hanım Ali'nin onunla konuşup konuşmadığını soruyordu. Korkut gelip Lamia'nın yanına, Ali'nin ayakları dibine oturmuştu. Lamia Ali'nin pantolon kıvrımını düzeltiyor, Ali, Gazi'yle bile konuşmuş olan bu şahane kişi özellikle kendine aitmiş gibi göğsü övünçle dolup taşıyordu.

Sarma tenceresini mutfağa götürüp ateşe vurmak için ayağa kalkan Hacer, "Gazi'nin hakkı ödenmez," diye konuştu. "Her aldığımız nefesi ona borçluyuz, Allah başımızdan eksik etmesin ama bir de dinimizle uğraşmayaydı!"

Lütfiye Hanım hışım gibi, "Sus ordan cahil, nankör kadın!" diye çemkirdi. "Kim kimin diniyle uğraşmış? Camilerin hepsi açı değil mi? Beş vakit namazında değil misin?"

Korkut, "Örümcek kafalı işte!" diye söylendi. (53)

They were all thrilled especially when they found out that Ali was also acquainted with the Ghazi, that he shook hands with him during a visit to the residence in Yalova on a summer day. Süsi wanted to learn the exact shade of the Ghazi's eye color, Lütfiye Hanım asked whether or not Ali had talked to him. Korkut had come and sat down next to Lamia, at Ali's feet. Lamia was fixing the crease on Ali's trousers, bursting with pride as if Ali, this magnificent person who even talked to the Ghazi, specially belonged to her.

Rising to go and put the saucepan filled with stuffed vine leaves on the stove in the kitchen, Hacer said, "What we owe to the Ghazi cannot be repaid. We owe each breath we take to him, may Allah keep him with us always but if only he didn't intrude with our religion."

Lütfiye Hanım snapped back at her, "Shut up you ignorant, ungrateful woman! Who intruded with whose religion? Aren't all the mosques open? Don't you perform your prayers five times a day?"

"Fogy she!" Korkut grumbled. (53)

Furthermore, another similar significance was added to Mazi Kalbimde Bir Yaradır (1988) through reference to the Turkish poet Nâzım Hikmet and the period in which his works were kept hidden and read in secret night meetings due to their ban:

"Yok, Boğaç Bey'e gidiyoruz. Boğaç Bey'de Nâzım Hikmet'in yeni şiirleri varmış. Onları okuyacak." (70)

Işıkları karartılmış bir odada, baskın tehlikesi altında yasak şiir okumanın nasıl olacağını merak ediyordu. (71)

"No, we are going to Boğaç Bey. Boğaç Bey has the new poems of Nâzım Hikmet. He will read them." (70) 
She was curious about what it would be like to read banned poems in a room with darkened lights under the risk of a raid. (71)

\section{Conclusion}

In this study, Turkish translator and writer Nihal Yeğinobalı's novel Eflatun Klz presented and received in the Turkish literary system under different categorizations as 'original' and 'translation' in three different periods was analyzed with the principal aim of providing a concept-oriented re-reading within the context of Translation Studies. In 1957, Eflatun Klz was serialized in Vatan as an indigenous novel; in 1964, it was published in book form by Altın Kitaplar as a seemingly interlingual translation which was later addressed as an example of 'pseudo-translation'; and in 1988, it was published again as an 'original' by Cem by changing the title to Mazi Kalbimde Bir Yaradır. The point of departure for the study being the obvious fact that the 1957 serial novel exists as a physical source text defying the alleged status of the 1964 text as a 'pseudo-translation,' which is a concept characterized by definition with the non-existence of a source text, the conceptual discussion within the confines of this study centered upon the concepts of pseudo-translation, intralingual translation, self translation and concealed translation, respectively. In this sense, the study suggests, just as the discovery of the non-existence of a source text reveals the status of a text as a pseudotranslation, the existence of a source text on which a 'pseudo-translation' is based may give birth to new conceptualizations such as 'pseudo pseudo-translation' or 'source-text based pseudo-translation.'

As a point of high importance considering the definitions of the concepts of pseudotranslation, self translation, and concealed translation in Translation Studies literature, it is observed that framing is generally restricted to only interlingual dimension, which is most likely driven by the tendency to see interlingual translation as 'translation proper.' This is deemed restrictive in the sense that it may end up with the general's missing out the specific. Based on Toury's (1995, 33-35) three postulates of "assumed translation" - the source-text postulate, the transfer postulate, the relationship postulate - suggested for interlingual translation but may apply to intralingual translation as well, this study defines the relations between the three Eflatun $\mathrm{Klz}$ texts as intralingual translation. Furthermore, on the grounds that this intralingual translation was accomplished by the same physical person, the study suggests a conceptual reframing for the 1964 and the 1988 texts - whose relations with the 
source text(s) are in a way concealed - as "concealed intralingual self translation" taking the concept of "intr-auto-translauthor" as a basis. Considering the fact that the 1988 text was presented as an 'original' with a change in the title without any mention of the two preceding texts in the peritexts, the status of Mazi Kalbimde Bir Yaradır as an 'original' in the customary sense may also be questioned asking whether it can be regarded as a 'pseudo-original' in this regard.

Needless to say, consideration of translational phenomena through rethinking established concepts enlarges the boundaries of Translation Studies, as well as contributing to the admission of a wider range of study objects into the field. In this sense, the present study suggesting a possible conceptual reframing for the specific case of Eflatun $\mathrm{Klz}$ in the Turkish literary system within the context of Translation Studies attempts to provide an insight into the importance of re-reading translational practices, as well as theoretical acceptance. 
transLogos 2018 Vol 1 Issue 1

trans Logos

Boy, Hülya, pp. 64-91

A Translation Studies Journal

Eflatun Klz within the Context of Translation Studies:

A Conceptual (Re)Framing

(c) Diye Global Communications diye.com.tr |diye@diye.com.tr

\section{Appendix}

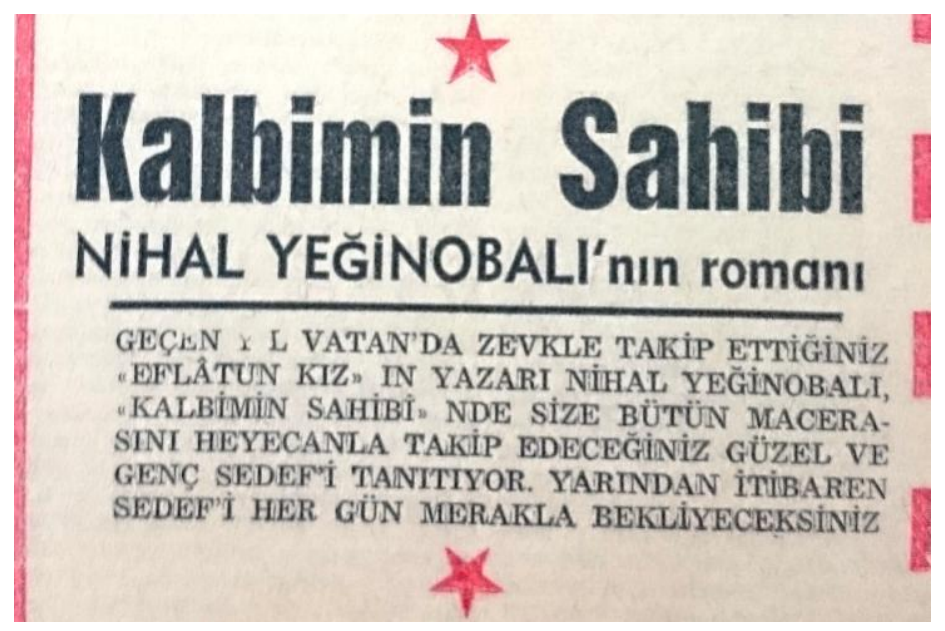

Figure 5. The advertisement of Nihal Yeğinobalı's serial novel Kalbimin Sahibi in Vatan dated 14 June 1958. 


\section{References}

Alt, Nil. 2008. "A Gender-Based Study of Nihal Yeğinobalı's Pseudo-Translation Genç Kızlar." MA thesis, Boğaziçi University.

Baker, Mona, ed. 1998. Routledge Encyclopedia of Translation Studies. London: Routledge.

Bengi-Öner, Işın. (1990) 1999. "Çeviribilim, Çeviri Kuramı ve Sözde Çeviriler." [Translation Studies, translation theory and pseudo-translations.] Chap. 1 in Çeviri Bir Süreçtir... Ya Çeviribilim? [Translation is a process... What about Translation Studies?] Istanbul: Sel.

. 1999. "Çeviriyle 40 Y1l: Nihal Yeğinobalı ile Bir Söyleşi." [40 years of translation: Interview with Nihal Yeğinobal1.] Chap. 1 in Çeviri Bir Süreçtir... Ya Çeviribilim? [Translation is a process... What about Translation Studies?] Istanbul: Sel.

Boy, Hülya. 2018. "Eflatun Kız'ın Türk Edebiyat ve Kültür Dizgesindeki Çeviri Macerasını Yeniden Düşünmek." [Rethinking the translational adventure of Eflatun $\mathrm{Klz}$ in the Turkish literary and cultural system.] Paper presented at the Enriching Translation Studies through Rereadings Symposium, Istanbul, March 28.

Canlı, Gülsüm. 2018. "Kavram Tanımlarının Ötesinde Bir Çeviri Eylemi: William Faulkner'ın Sanctuary Adlı Romanının Türk Erek Dizgesindeki Serüveni." [A translational act beyond definitions of concepts: The adventure of William Faulkner's Sanctuary in the Turkish target system.] In Çeviribilimde Güncel Tartışmalardan Kavramsal Sorgulamalara [From recent discussions to conceptual reflections in Translation Studies], edited by Seda Taş, 283-314. Istanbul: Hiperyayın.

Canlı, Gülsüm and Ayşe Banu Karadăg. 2017. "William Faulkner'ın Sanctuary Adlı Romanının Farklı Çeviri Türlerindeki Örnekleri Üzerine Betimleyici Bir Çalışma." [A descriptive study on the examples of William Faulkner's Sanctuary in different translation types.] Paper presented at the IV. Yildiz Social Sciences Congress, Istanbul, December 21-22.

Chesterman, Andrew. 1997. Memes of Translation. Amsterdam: John Benjamins.

Ersoy, Tarık. 1988. "Utandığım İçin Açıklayamadım." [I couldn't explain because I was embarrassed.] Cumhuriyet, June 5.

Ewing, Vincent. 1950. Genç Kızlar [Young girls]. Translated by Nihal Yeğinobalı. Istanbul: Türkiye.

1964. Eflatun Klz [Lilac girl]. Translated by Nihal Yeğinobalı. Istanbul: Altın Kitaplar. 
Grutman, Rainier and Trish Van Bolderen. 2014. "Self-Translation." In A Companion to Translation Studies, edited by Sandra Bermann and Catherine Porter, 323-332. West Sussex: Wiley Blackwell.

Hermans, Theo. 1997. "Translation as Institution." In Translation as Intercultural Communication: Selected Papers from the EST Congress, Prague 1995, edited by Mary Snell-Hornby, Zuzana Jettmarová and Klaus Kaindl, 3-20. Amsterdam: John Benjamins.

Jakobson, Roman. 1959. "On Linguistics Aspects of Translation." In On Translation, edited by Reuben Arthur Brower, 232-239. Cambridge: Harvard University Press.

Montini, Chiara. 2010. "Self-Translation." In Handbook of Translation Studies Volume 1, edited by Yves Gambier and Luc Van Doorslaer, 306-308. Amsterdam: John Benjamins.

O'Sullivan, Carol. 2011. "Pseudotranslation." In Handbook of Translation Studies Volume 2, edited by Yves Gambier and Luc Van Doorslaer, 123-125. Amsterdam: John Benjamins.

Öztürk Kasar, Sündüz. 2009. "Les Pseudo-Traductions de Nihal Yeğinobalı: Auctorialité Féminine et Émancipation." [The pseudo-translations of Nihal Yeğinoball: Female authorship and emancipation.] In Femmes Écrivains à la Croisée des Langues 17002000, edited by Agnese Fidecaro, Henriette Partzsch, Suzan van Dijk and Valérie Cossy, 187-197. Geneva: Métis Presses.

Öztürk Kasar, Sündüz and Serap Gün Birdane. 2006. "Sözde-Çeviride Söylem ve Biçem." [Discourse and style in pseudo-translation.] In VI. International Language, Literature and Stylistics Symposium Proceedings, 494-501.

Rambelli, Paolo. 2009. "Pseudotranslation." In Routledge Encyclopedia of Translation Studies, edited by Mona Baker and Gabriela Saldanha, 208-211. London: Routledge.

Tahir Gürçağlar, Şehnaz. 2010. "Scouting the Borders of Translation: Pseudotranslation, Concealed Translations and Authorship in Twentieth-Century Turkey." Translation Studies, 3 (2): 172-187. doi:10.1080/14781701003647384.

Toury, Gideon. 1995. Descriptive Translation Studies and Beyond. Amsterdam: John Benjamins.

Yeğinobal1, Nihal. 1957. Eflatun Klz [Lilac girl]. Vatan. April 23-July 29.

1988. Mazi Kalbimde Bir Yaradır [The past is a wound in my heart]. 2nd ed. Istanbul: Cem. 